\title{
FINANCIAL LITERACY AND STOCK PRICE INFORMATIVENESS: A CROSS-COUNTRY STUDY
}

\author{
Anita TODEA* \\ Babeș-Bolyai University, Romania
}

\begin{abstract}
This paper examines the impact of financial literacy on stock price informativeness in a sample of firms from 20 countries. Using four measures of stock price informativeness, we find a significant relationship between higher financial literacy and higher stock price informativeness. The individual investors' contribution regarding the incorporation of specific information into stock prices includes private information also and not mere specific information in the general sense. Financial knowledge is the key element that helps individual investors to incorporate specific information into stock prices.
\end{abstract}

JEL Classification: C13, G14, G15, I22

Keywords: price informativeness, financial literacy, financial knowledge, firmspecific information, private information

\section{Introduction}

The informativeness of prices facilitates the efficient allocation of resources. The hypothesis that managers can learn from the information in the stock price about the prospects of their own firms is supported by both theoretical models and empirical results. The basic idea is that investors incorporate specific information into stock prices about future investment and financing opportunities, thus guiding them in making corporate decisions, such as the decision on corporate investments. This theory is supported by the theoretical models proposed by Dow and Gorton (1997) and Subrahmanyam and Titman (1999) and by the empirical studies of Durnev et al. (2004), Chen et al. (2007), Bakke and Whited (2010), or Fressard (2012). See Bond et al. (2012) for an excellent survey on this topic.

\footnotetext{
* Corresponding author. Address: Department of Statistics, Forecasting, Mathematics, Faculty of Economics and Business Administration, Babes-Bolyai University,Teodor Mihali 58-60, 400591 Cluj-Napoca, Romania, Tel. +40.264 4186 52, E-mail: anita.todea@econ.ubbcluj.ro
} 
The purpose of this study is to see if higher financial literacy promotes a better incorporation of firm specific information into stock prices. Validation of such a result is important on several plans. First, financial literacy could be an important omitted variable in studies that examine cross-country differences in stock price informativeness. Second, the result would support the positive impact of individual investors in stock price formation, as debates about their contribution to the incorporation of specific information into stock prices are far from being completed in the literature. Thus, Odean (1998), Barber and Odean (2000) or Kumar (2009) have shown that individual investors are subject to fads and psychological biases, thus having a negative impact on stock prices. On the other hand, Evans (2008), Kelley and Tetlok (2013) or Wang and Zhang (2015) highlight the individual investors' positive effect on prices. Last but not least, it is highlighted that financial education improves financial outcomes, with important policy implications (see Hastings et al., 2003 for more details).

A number of studies indirectly support the hypothesis of this study, showing that financial literacy is predictive for investment behaviors of individual investors. Thus, Graham et al. (2009) have shown that financial skills are positively associated with better portfolio diversification, reduced home bias effect and more frequent stock trading. Financial literate persons tend to invest more in stock markets (Christelis et al., 2010, van Rooij et al., 2012) and choose a low fee investment portfolio (Choi et al., 2011).

\section{Measurement of variables and model specification}

\subsection{Measurement of stock price informativeness}

The endogenous variable of the study is stock price informativeness, which is quantified by two measures known in the literature: price synchronicity introduced by Mork et al. (2000) and the information measure of Llorente et al. (2002).

Price synchronicity, $R^{2}$, is the most popular and most commonly used measure of stock price informativeness. To distinguish firm-specific stock price variations from market-wide variations we estimate annually the model proposed by Jin and Myers (2006):

$$
\begin{aligned}
& r_{i, j, t}=\alpha_{i, j}+\beta_{1, i} r_{L, j, t-2}+\beta_{2, i} r_{L, j, t-1}+\beta_{3, i} r_{L, j, t}+\beta_{4, i} r_{L, j, t+1}+\beta_{5, i} r_{L, j, t+2} \\
& +\beta_{6, i} r_{W, t-2}++\beta_{7, i} r_{W, t-1}++\beta_{8, i} r_{W, t}++\beta_{9, i} r_{W, t+1}+\beta_{10, i} r_{W, t+2}+\varepsilon_{i, j, t}
\end{aligned}
$$

where $r_{i, j, t}$ is the weekly return of stock $i$ of country $j$ in week $t$ of year, $r_{L, j, t}$ is the weekly local market return of country $j$ in week $t$, and $r_{W, t}$ is the weekly global market return in week $t$. Lead and lag terms are included to correct for nonsynchronous trading, phenomenon encountered in low-liquid stocks. Price synchronicity $\left(R_{i, j}^{2}\right)$ is the coefficient of determination from model (1). It measures the relative amount of market-wide information versus firm-specific information impounded into stock price in a year, thus being an inverse measure of stock price informativeness. Given the cross-country nature of this study, we use an equally weighted average of the $R_{i, j}^{2} \mathrm{~s}$ of the individual stocks in country $j$, denoted with $R_{j}^{2}$. We apply a logistic transformation to this variable in order to get a direct measure of stock price informativeness, accounting for the limitation within the interval $[0,1]$ : 


$$
\Psi_{j}=\log \left(\frac{1-R_{j}^{2}}{R_{j}^{2}}\right)
$$

Price synchronicity is a debated measure in literature, and it is not clear whether it reflects informativeness or noise traders (Teoh et al., 2009, Chan and Chan, 2014) or whether it is a direct or inverse measure (Dasgupta et al. 2010; Kan and Gong 2017). In addition, through construction, it captures all the specific information and not the mere private information that is really useful to companies' managers in their decisions.

For these reasons, the second measure used in this study is the information measure of Llorente et al. (2002). Annual amount of private trading information $\gamma_{i j}$ is estimated for each firm-year from the time-series regression:

$$
r_{i, j, t}=a_{i, j}+b_{i, j} r_{i, j, t-1}+\gamma_{i, j}\left(r_{i, j, t-1} \times V_{i, j, t-1}\right)+\varepsilon_{i, j, t}
$$

where $r_{i, j, t}$ is the return of stock $i$ of country $j$ and $V_{i, j, t-1}$ is log daily turnover of stock $i$ detrended by substracting a 200 trading day moving average. Higher values of $\gamma_{i, j}$ denote more information-based trading incorporated in stock prices. The intuition behind this interpretation is that in periods of high volume, stocks with a a high degree of information-based trading tend to display positive return autocorrelation. Our dependent variable $\gamma_{j}$ is an equally weighted average of the $\gamma_{i, j}$ of the individual stocks in country $j$.

\subsection{Financial literacy measures}

The exogenous variable of interest in this study is the financial literacy index. Various international institutions have conducted surveys on groups of countries, most notable being those conducted by Standard and Poor ${ }^{1}$ in collaboration with several institutions, Mastercard ${ }^{2}$ for Asian and European countries, and recently by the OECD. Of these, we chose in our study the OECD's survey, the main argument being the complexity of the administered questionnaires and the sample size of individuals. The full report of this inquiry can be found at: http://www.oecd.org/finance/ oecd-infe-survey-adult-financial-literacy-competencies.htm.

The survey is conducted on 30 countries, of which 17 are OECD members. The sample consists of 51,650 adults aged 18 to 79 , the questions in the questionnaires being focused on relevant aspects of financial knowledge, financial behavior and attitudes to longer-term financial planning. The financial literacy index is the highest for France (14.9p) and the lowest for Poland (11.6p). It is also noticed that the score of OECD member countries is significantly higher than that of non-member countries. For robustness, we will use the Financial Knowledge Index built on a set of 7 questions. Somewhat expected taking into account other measurements in literature, it takes the highest value for Hong Kong / China (5,8p) and the lowest for Malaysia and Belarus $(3,8)$.

${ }^{1}$ For details, see http://gflec.org/initiatives/sp-global-finlit-survey/.

${ }^{2}$ For details, see https://www1.mastercard.com/content/intelligence/en/search.Report.html. 


\subsection{Controls variables}

Based on the arguments and findings of previous studies (Mork et al., 2000, Chan and Hameed, 2006, Fernandes and Ferreira, 2009, Eun et al., 2015) we use the same control variables. Following Jin and Myers (2006), we construct an opaqueness measure, the diversity of analyst forecasts, as follows:

$$
\text { Diversity }=\frac{\widehat{\sigma} / \widehat{\mu}}{\sqrt{N}}
$$

where: $\hat{\sigma}$ is the standard deviation of the company's earnings forecasted by analysts in the following year, $\hat{\mu}$ is the mean forecast and $N$ is the number of analysts following that company. The necessary data, with an annual frequency, are extracted from I/B/E/S International, taking into account only the constituents of stock market indexes. The second variable, Good Governement Index, is the sum of percentile ranks of government effectiveness and control of corruption. The two dimensions are constructed by Kaufmann et al. (2010) and come from Worldwide Governance Indicators. These data, along with GDP per capita, GDP growth volatility, the number of stocks and country geographic size are extracted from the World Bank database. Other control variables are industrial and firm Herfindahl indices determined on the basis of all quoted stocks on the markets in our sample. The last control variable is the cultural dimension - individualism/collectivism obtained from Hofstede et al. (2010).

\section{The data and descriptive statistics}

Of the 30 countries in the OECD report, we have retained 20 - the ones which have developed or emerging stock markets according to $\mathrm{MSCl}$, respectively 11 and 9. From the Thomson Eikon database, we extracted for the period 2004-2016 the weekly and daily closing prices in order to build the two measures of price informativeness, and the daily trading volumes. We applied a stock selection filter by retaining in sample only those stocks that were traded in at least $80 \%$ of the stock market sessions each year. Thus, a sample of 11,413 stocks was obtained. At the same time, we have extracted the equity weekly prices for each local stock market index and the $\mathrm{MSCl}$ World Index. All this data is denominated in dollars. Table 1 provides a summary of our sample.

The values of $R^{2}$ in Table 1 are not similar to those of Mork et al. (2000), which state that in developed markets price synchronicity is lower, therefore more specific information is incorporated into stock prices. They confirm the results of Eun et al. (2015) and makes us believe that financial literacy could be an explanatory variable in this respect. In the case of measure $\gamma_{j}$ it is observed that the developed markets incorporate more private information than the emerging ones, the average $\gamma_{j}$ being 0.015 and 0.0031 , respectively. This, corroborated with the observation that the most financially literate nations are those with developed capital markets, makes us believe that financial literacy contributes to better incorporation of private information into stock prices. 
Table 1. Summary statistics of the sample

\begin{tabular}{lcccccc}
\hline Country & Stock index & $\begin{array}{c}\text { Number } \\
\text { of stocks }\end{array}$ & $\boldsymbol{R}^{\mathbf{2}}$ & $\boldsymbol{\gamma}_{\boldsymbol{j}}$ & $\boldsymbol{F} \boldsymbol{F}$ & $\boldsymbol{F}$ \\
\hline Austria & ATX & 68 & 0,3772 & $-0,0049$ & 14.2 & 4.9 \\
Belgium & BEL20 & 329 & 0,3557 & 0,0108 & 14.3 & 4.9 \\
Brazil & BOVESPA & 266 & 0,3372 & 0,0206 & 12.1 & 4.3 \\
Canada & TSX60 & 745 & 0,3868 & 0,0481 & 14.6 & 4.9 \\
Czech republic & PX & 17 & 0,2964 & $-0,0027$ & 12.6 & 4.4 \\
Finland & OMXH25 & 141 & 0,4054 & 0,0203 & 14.8 & 5.2 \\
France & CAC40 & 820 & 0,3269 & $-0,00008$ & 14.9 & 4.9 \\
Hong Kong & HSI & 1352 & 0,2866 & 0,00043 & 14.4 & 5.8 \\
Hungary & BUX & 44 & 0,2208 & 0,0200 & 12.4 & 4.7 \\
Korea (South) & KS11 & 2195 & 0,3713 & $-0,0027$ & 14.4 & 5.4 \\
Malaysia & KLSE & 918 & 0,2895 & 0,0014 & 12.3 & 3.6 \\
Netherlands & AEX & 104 & 0,4173 & $-0,0042$ & 13.4 & 4.9 \\
New Zeeland & NZ50 & 146 & 0,3737 & 0,0318 & 14.4 & 5 \\
Norway & OBX & 172 & 0,3741 & 0,00259 & 14.6 & 5.2 \\
Poland & WIG20 & 856 & 0,2123 & 0,0081 & 11.6 & 4.4 \\
Portugal & PSI20 & 57 & 0,4051 & $-0,0258$ & 14 & 4.8 \\
Russian & RTS & 658 & 0,2669 & $-0,0056$ & 12.2 & 4.1 \\
Federation & SET50 & 726 & 0,3750 & $-0,0018$ & 12.8 & 3.9 \\
Thailand & BIST30 & 417 & 0,4990 & $-0,0087$ & 12.5 & 4.6 \\
Turkey & FTSE100 & 1382 & 0,3325 & 0,0369 & 13.1 & 4.2 \\
UK & & & & &
\end{tabular}

Note. The $R^{2}$ and $\gamma_{j}$ are averages of annually values of synchronicity and information measure of Llorente. $F L$ and $F K$ are financial literacy index and financial knowledge index from OECD.

Source: author's calculations

\section{Basic empirical results}

To test the relation between the financial literacy and stock price informativeness, we estimate several specifications of the following model:

$$
\text { StocPriceInform }_{j, t}=\alpha_{0}+\alpha_{1} \text { FIN }_{j}+\sum_{k} \beta_{k} \text { Controls }_{k, j, t}+\varepsilon_{j, t}
$$

where StocPriceInform f $_{j, t}$ is each of the two measures proposed for the stock price informativeness of country $j$ in year $t, F I N_{j}$ is financial literacy index respectively financial knowledge index, Controls is a set of control variables and $\varepsilon_{j, t}$ is an error term. 
Table 2. Regressions results

\begin{tabular}{|c|c|c|c|c|c|c|}
\hline & \multicolumn{6}{|c|}{ Dependent variable } \\
\hline & $\Psi_{j}$ & $\gamma_{j}$ & $\Psi_{j}$ & $\gamma_{j}$ & $\Psi_{j}$ & $\gamma_{j}$ \\
\hline & (1) & (2) & (3) & (4) & (5) & (6) \\
\hline FIN & $\begin{array}{c}0,0608^{*} \\
(1.67)\end{array}$ & $\begin{array}{c}0.0024^{*} \\
(1.78)\end{array}$ & $\begin{array}{c}0.065^{\star \star \star} \\
(3.57)\end{array}$ & $\begin{array}{l}0.006^{\star \star \star} \\
(4.23)\end{array}$ & $\begin{array}{l}0.135^{\star} \\
(1.86)\end{array}$ & $\begin{array}{c}0.026^{\star \star \star} \\
(3.56)\end{array}$ \\
\hline $\begin{array}{c}\text { Analyst diversity } \\
\text { rank }\end{array}$ & - & - & $\begin{array}{l}0.0055 \\
(1.35)\end{array}$ & $\begin{array}{c}0.030 * \star \star \\
(6.24)\end{array}$ & $\begin{array}{c}0.079 * * \\
(2.26)\end{array}$ & $\begin{array}{l}0.032^{* * *} \\
(6.90)\end{array}$ \\
\hline Good & & & & & 0.0001 & $0.001^{* \star *}$ \\
\hline $\begin{array}{l}\text { Government } \\
\text { Index }\end{array}$ & - & - & $\begin{array}{l}0.001 \\
(0.36)\end{array}$ & $\begin{array}{c}0.002^{\star \star \star} \\
(6.96)\end{array}$ & $(0.15)$ & (5.51) \\
\hline $\begin{array}{l}\text { Ln(GDP per } \\
\text { capita) }\end{array}$ & - & - & $\begin{array}{c}-0.173^{\star} \\
(-1.95)\end{array}$ & $\begin{array}{c}-0.031^{\star \star \star} \\
(-3.55)\end{array}$ & $\begin{array}{c}-0.216^{\star} \\
(-2.08)\end{array}$ & $\begin{array}{c}-0.04^{\star \star \star} \\
(-3.80)\end{array}$ \\
\hline $\begin{array}{l}\text { GDP growth } \\
\text { volatility }\end{array}$ & - & - & $\begin{array}{l}-1.417 \\
(-0.59)\end{array}$ & $\begin{array}{l}0.094 \\
(0.22)\end{array}$ & $\begin{array}{l}-1.796 \\
(-0.67)\end{array}$ & $\begin{array}{l}0.059 \\
(0.15)\end{array}$ \\
\hline $\begin{array}{l}\text { Ln(number of } \\
\text { stocks) }\end{array}$ & - & - & $\begin{array}{l}0.019 \\
(1.59)\end{array}$ & $\begin{array}{c}0.004^{\star *} \\
(3.09)\end{array}$ & $\begin{array}{l}0.001 \\
(0.07)\end{array}$ & $\begin{array}{l}-0.001 \\
(-0.04)\end{array}$ \\
\hline Ln(country size) & - & - & $\begin{array}{c}-0.038^{* *} \\
(-2.58)\end{array}$ & $\begin{array}{l}0.003^{*} \\
(1.83)\end{array}$ & $\begin{array}{l}-0.036^{\star} \\
(-2.10)\end{array}$ & $\begin{array}{l}0.001 \\
(0.88)\end{array}$ \\
\hline $\begin{array}{l}\text { Ind. Herfindahl } \\
\text { index }\end{array}$ & - & - & $\begin{array}{l}-0.517^{*} \\
(-2.15)\end{array}$ & $\begin{array}{l}0.116^{\star *} \\
(3.18)\end{array}$ & $\begin{array}{l}-0.901^{*} \\
(-2.14)\end{array}$ & $\begin{array}{l}0.015 \\
(0.25)\end{array}$ \\
\hline $\begin{array}{l}\text { Firm Herfindahl } \\
\text { index }\end{array}$ & - & - & $\begin{array}{l}0.251 \\
(0.74)\end{array}$ & $\begin{array}{l}-0.030 \\
(-0.72)\end{array}$ & $\begin{array}{l}0.567 \\
(1.31)\end{array}$ & $\begin{array}{l}0.057 \\
(0.91)\end{array}$ \\
\hline Individualism & - & - & $\begin{array}{c}0.004^{* *} \\
(2.88)\end{array}$ & $\begin{array}{c}0.0001 \\
(0.26)\end{array}$ & $\begin{array}{l}0.006^{*} \\
(1.92)\end{array}$ & $\begin{array}{l}0.001^{*} \\
(1.93)\end{array}$ \\
\hline Constant & $\begin{array}{l}1.110 \star \star \star \\
(2.93)\end{array}$ & $\begin{array}{l}-0.027 \\
(-0.66)\end{array}$ & $\begin{array}{l}1.077 \\
(1.61)\end{array}$ & $\begin{array}{c}-0.180 * \star \\
(-2.83)\end{array}$ & $\begin{array}{c}1.947^{\star \star} \\
(2.51)\end{array}$ & $\begin{array}{c}0.028 \\
(-0.29)\end{array}$ \\
\hline$R$-squared & 0.076 & 0.081 & 0.260 & 0.621 & 0.278 & 0.632 \\
\hline
\end{tabular}

Note: Robust standard errors adjusted with country level clustering are reported in parentheses. * ${ }^{* *}$, and *** indicate statistical significance at the $10 \%, 5 \%$, and $1 \%$ levels, respectively.

Source: author's calculations

We present the estimation results in Table 2. In models (1) and (2) we first consider a univariate model in which we regress $\Psi_{j}$ and $\gamma_{j}$ on the financial literacy index. In both cases the parameters are significant at $10 \%$ significance level indicating a direct link between stock price informativeness and the financial literacy index. With the introduction of control variables, the marginal effect of financial literacy on stock price informativeness increases from 0.0608 to 0.065 in model (3) and from 0.0024 to 0.006 in model (4). Both parameters are this time significant at $1 \%$ significance level. In the case of control variables, for the Governement Index and Individualism the signs of the coefficients are in line with those obtained by Fernandes and Ferreira (2009) and Eun et al. (2015), but for the Analyst diversity rank and GDP per capita variables the situation is different.

Financial education is the main component of the financial literacy index. A direct link between it and stock price informativeness measures is confirmed in Models 5 and 6 and supports the need to implement public policies that will lead to improved financial education. 
Another interesting aspect is given by $R^{2}$ values. It is noticeable that it is higher when we use $\gamma_{j}$ as a proxy for stock price informativeness than $\Psi_{j}$. The result is remarkable given that $\gamma_{j}$, by its construction, has the potential to capture more accurately the incorporation of private information into stock prices than $\Psi_{j}$.

In addition, we studied whether the other two components of the financial literacy index - financial behavior and attitudes to long-term financial planning - have an impact on price informativeness. Unreported results show that their parameters are not significant, indicating that financial knowledge is the main component of financial literacy with an impact on stock price informativeness.

\section{Robustness tests}

In Table 5 we present the results of several robustness tests. In models (1) - (4) price informativeness is measured using idiosyncratic volatility and illiquidity measure proposed by Amihud (2002). In models (5) and (6) we employ an alternative measure for financial knowledge from Executive Opinion Survey - the IMD World Competitiveness Yearbook (WCY).

Table 3. Robustness tests

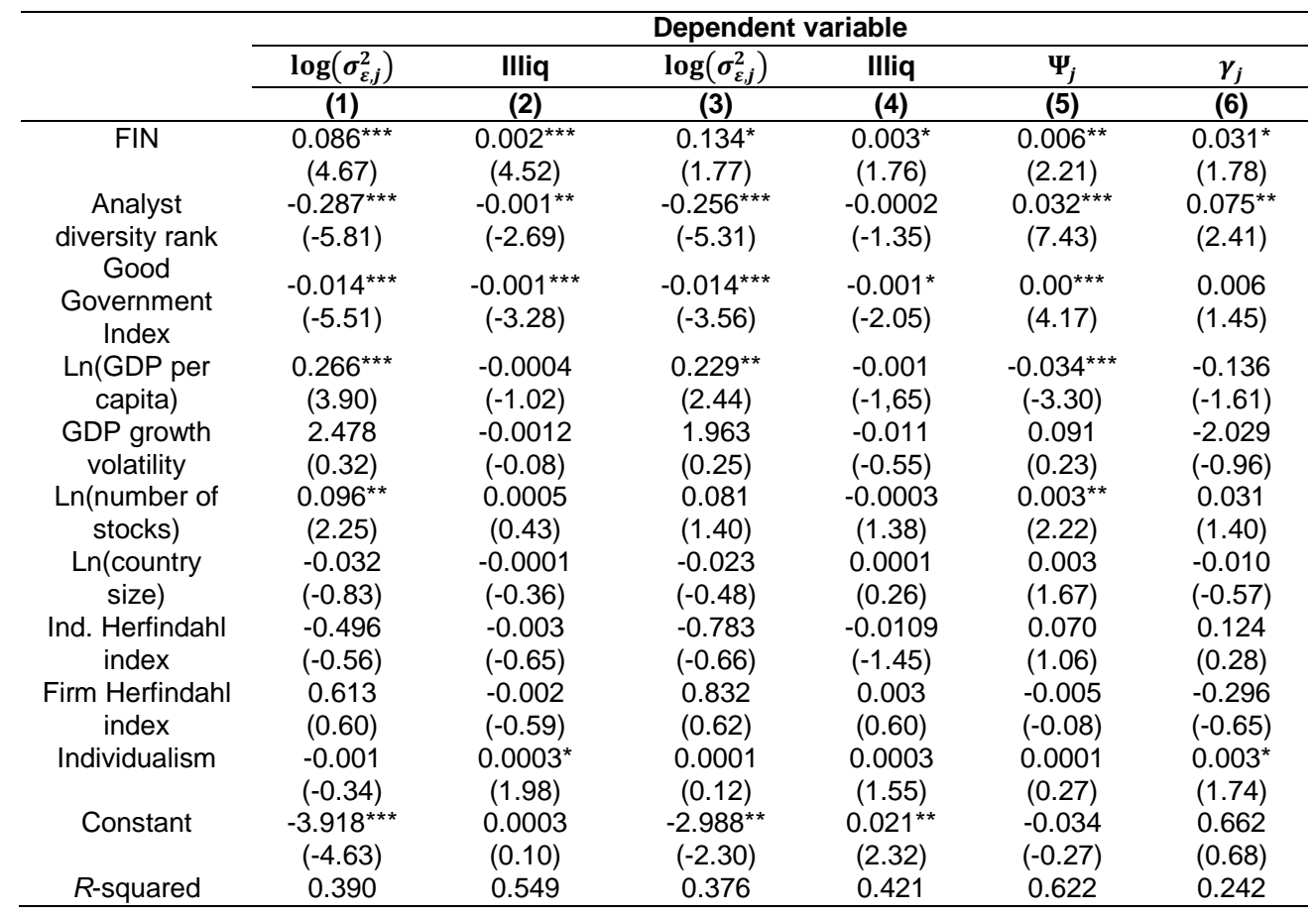

Note: Robust standard errors adjusted with country level clustering are reported in parentheses. * , **, and

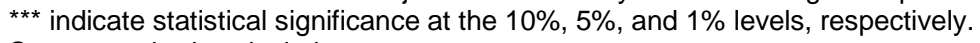

Source: author's calculations 
Idiosyncratic volatility is the residual variance from model (1). In fact, $\Psi_{j}$ can be decomposed into firm-specific variation and market-wide variation:

$$
\Psi_{j}=\log \left(\frac{\sigma_{\varepsilon, j}^{2}}{\sigma_{m, j}^{2}}\right)=\log \left(\sigma_{\varepsilon, j}^{2}\right)-\log \left(\sigma_{m, j}^{2}\right)
$$

The variable $\log \left(\sigma_{\varepsilon, j}^{2}\right)$ is the logarithm of average residual sum of squares and $\log \left(\sigma_{m, j}^{2}\right)$ is the logarithm of average explained sum of squares from Eq. (1). Intuitively, a higher $\Psi_{j}$ indicates the power of firm-specific variation $\left(\sigma_{\varepsilon, j}^{2}\right)$ relative to market-wide variation $\left(\sigma_{m, j}^{2}\right)$ in explaining the stock price movements of firms in country $j$. The central argument underlying this measure is that price synchronicity and idiosyncratic volatility are not equivalent in measuring the incorporation of specific information into stock prices. Li et al. (2014) show that the two may lead to contradictory inferences, especially if there is a correlation between systematic risk and the variable of interest, such as financial literacy or financial knowledge. We use $\log \left(\sigma_{\varepsilon, j}^{2}\right)$ as an endogenous variable in models (1) and (3) of Table 3. The positive parameters of FIN variable indicate a direct relationship between the financial literacy index/ financial knowledge index and the incorporation of specific information into stock prices.

The illiquidity ratio of Amihud (2002) was employed in the literature as measure of stock price informativeness by Ferreira et al. (2011), Fresard (2012) or De Cesari et al. (2015). For each stock, we calculated this measure annually using the relation:

$$
\text { Illiq }_{i, t}=\frac{1}{D_{i, t}} \sum_{\tau=1}^{D_{i, t}} \frac{\left|R_{i, \tau}\right|}{\text { Volume }_{i, \tau}}
$$

where $D_{i, t}$ is the number of valid observation days for firm $i$ in year $t, R_{i, \tau}$ is firm i's daily return and Volume $_{i, \tau}$ is the dollar volume of firm $i$ on day $\tau$. Illiq $q_{i, t}$ is a price impact measure. According to Kyle (1985), the magnitude of the price impact should be a positive function of the perceived amount of informed trading on stock prices. The endogenous variable used in models (2) and (4) of Table 3 is an equally weighted average calculated for each market and each year. The positive and significant parameters indicate that financial literacy (model (2)) and financial knowledge (model (4)) have a positive impact on the incorporation of private information.

In models (5) and (6) of Table 3 we used an alternative measure of financial knowledge from the Executive Opinion Survey - the IMD World Competitiveness Yearbook (WCY). This was recently used by Giofre (2017), which shows that it is a significant factor explaining foreign portfolio investment. In this case also, the positive parameters of the FIN variable indicate a positive relationship between financial knowledge and the incorporation of specific information into stock prices, regardless of whether the measure used is price synchronicity or that of Llorente (2002).

\section{Conclusions}

In this study we have formulated and validated the hypothesis that the stock prices are more informative on the stock markets of more financial literate nations. 
Cross-country results are obtained for 20 stock markets for the period 2004-2016. Four price informativeness measures have been used, taking into account all listed stocks in these markets. Price synchronicity and idiosyncratic volatility measure the incorporation of specific information into stock prices, while the measures of Llorente (2002) and Amihud (2002) particularly capture the incorporation of private information into stock prices. It can be seen that the contribution of individual investors regarding the incorporation of specific information into stock prices also includes private information and not only the specific information in the general sense. In addition, we have found that financial knowledge is the main component of financial literacy that contributes to better incorporation of specific/private information into stock prices.

Our results have implications in several directions. First, the study suggests that financial literacy is an important omitted variable in studies that examine crosscountry differences in stock price informativeness. This variable should be included alongside with the traditional ones from literature when researchers draw crosscountry inferences from stock markets. Second, on the assumption that institutional investors have higher capacities and knowledge that are not measured by the financial literacy index, our study supports the positive impact of individual investors in the process of stock price formation. Third, the results of our study join the rich literature that demonstrates the need to adopt public policies aimed to increase the nations' financial knowledge.

\section{References}

Amihud Y. (2002) Illiquidity and stock returns: cross-section and time- series effects. Journal of Financial Markets, 5, 31-56

Bakke T.E., Whited T.M. (2010) Which firms follow the market? An analysis of corporate investment decisions. Review of Financial Studies, 23(5),1941-80

Barber B., Odean, T. (2000) Trading is hazardous to your wealth, the common stock investment performance of individual investors, Journal of Finance, 55, 773-806

Bond P., Edmans A., Goldstein I. (2012) The Real Effects of Financial Markets, Annual Review of Financial economics, 4, 339-360

Chan K., Hameed A. (2006) Stock Price Synchronicity and Analyst Coverage in Emerging Markets, Journal of Financial Economics, 80, 115-47

Chan K., Chan Y.C. (2014) Price Informativeness and Stock Return Synchronicity: Evidence from the Pricing of Seasoned Equity Offerings, Journal of Financial Economics, 114, 36-53

Chen Q., Goldstein I., Jiang W. (2007) Price informativeness and investment sensitivity to stock price, Review of Financial Studies 20(3), 619-50

Choi J., Laibson D., Madrian B.C. (2011) $\$ 100$ bills on the sidewalk: suboptimal investment in 401(k) plans, Review of Economic and Statistics, 93(3), 748-763

Christelis D., Jappelli T., Padula M. (2010) Cognitive abilities and portfolio choice, European Economic Review, 54(1), 18-38

Dasgupta S., Gan J., Gao N. (2010) Transparency, Price Informativeness, and Stock Return Synchronicity: Theory and Evidence, Journal of Financial and Quantitative Analysis, 45, 1189-220

Dow J., Gorton G. (1997) Stock Market Efficiency and Economic Efficiency: Is There a Connection?, Journal of Finance, 52, 1087-1129 
Durnev A., Morck R., Yeung B. (2004) Value Enhancing Capital Budgeting and FirmSpecific Stock Return Variation, Journal of Finance, 59, 65-10

Eun C.S., Wang L., Xiao S.C. (2015) Culture and R2, Journal of Financial Economics, 115 (2), 283-303

Evans A. (2010) Do individual investors affect share price accuracy? some preliminary evidence. University of Michigan Law School The John M. Olin Center for Law \& Economics Working Paper Series

Fernandes N., Ferreira, M.A. (2009) Insider Trading Laws and Stock Price Informativeness, Review of Financial Studies, 22, 601-644

Fressard L. (2012) Cash savings and Stock Price Informativeness, 16(4), 985-1012

Giofre M. (2017) Financial education, investor protection and international portfolio diversification, Journal of International Money and Finance, 71, 111-139

Graham J., Harvey C., Huang H. (2009) Investor competence, trading frequency, and home bias, Management Science, 55(7), 1094-1106

Hastings J.S., Madrian B.C., Skimmyhorn W.L. (2013) Financial Literacy, Financial Education and Economics Outcomes, Annual Review of Economics, 1 (5), 347-373

Hofstede, G., Hofstede, G., Minkov, M., 2010. Cultures and Organizations, Software of the Mind, third ed. McGraw-Hill, New York

Jin L., Myers S. (2006) R2 around theworld, Journal of Financial Economics, 79, 257-292

Kan S., Gong S. (2017) Does High Stock return synchronicity Indicate High or Low Price Informativeness? Evidence from a regulatory experiment, International Review of Finance, https://doi.org/10.1111/irfi.12157

Kaufmann D., Kraay A., Mastruzzi M. (2010) The Worldwide Governance Indicators: A Summary of Methodology, Data and Analytical Issues, World Bank Policy Research Working Paper No. 5430 http://papers.ssrn.com/sol3/papers.cfm? abstract_id=1682130

Kelley E., Tetlock P. (2013) How wise are crowds? insights from retail orders and stock returns, Journal of Finance, 68, 1229-1265

Kumar A. (2009) Who gambles in the stock market? Journal of Finance, 64, 1889-1933

Kyle A.S. (1985) Continuous Auctions and Insider Trading, Econometrica 53, 1315-1336

Li B. (2014) $R^{2}$ and isiosyncratic Risk Are Not Interchangeable, The Accounting Review, 89(6), 2261-2295

Llorente G., Michaely R., Saar G., Wang J. (2002) Dynamic Volume-Return Relation of Individual Stocks, Review of Financial Studies, 15, 1005-1047

Morck, R., Yeung B., Yu W. (2000) The Information Content of Stock Markets: Why do Emerging Markets have Synchronous Stock Price Movements?, Journal of Financial Economics, 59, 215-260

Odean T. (1998) Are investors reluctant to realize their losses?, Journal of Finance, 53, 1775-1798

Subrahmanyam A., Titman S. (1999) The Going-Public Decision and the Development of Financial Markets, Journal of Finance, 54, 1045-1082

Teoh S.H., Yang Y.G., Zhang Y. (2009) R-Square and Market Efficiency', SSRN Working Paper. Available at https://ssrn.com/abstract $=926948$

Van Rooij M., Lusardi A., Alessie R. (2011) Financial literacy and stock market participation. Journal of Financial Economics, 2011, 101(2), 449-472

Wang Q., Zhang J. (2015) Does individual investor trading impact firm valuation?, Journal of Corporate Finance, 35, 120-135 